\title{
特集：生物がみる光・生物をみる光〜生物物理学を照らす七色の光〜
}

\section{特集「生物がみる光·生物をみる光〜生物物理学を 照らす七色の光〜」に寄せて}

\author{
山下高廣, 今元 泰 京都大学大学院理学研究科生物物理学教室
}

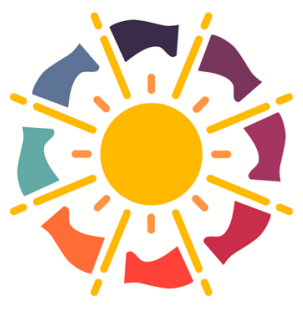

INTERNATIONAL YEAR OF LIGHT 2015
2015 年は「光と光技術の 国際年」（International Year of Light and Light-based Technologies）である.これは, イブ ン・アル・ハイサムの光学研 究から 1000 年，アルベルト・ アインシュタインの一般相対 性理論から 100 年, チャール ズ・カオの光ファイバの提唱 から 50 年など， 2015 年が光 にとって節目となる重要な年であることをふまえて国 際連合総会により定められたものである。この国際光 年宣言に関連し，国内でも各種のシンポジウムやイベ ントが開かれている。それらについてホームページか ら情報を得ることができ，参加された経験のある方も 多いのではないかと思う（本特集提案者もそのような 関連を知らず，昨冬に東京上野の国立科学博物館で開 催されていた「ヒカリ展」を訪れていた)。

生物物理学会でも，物理学と生物学の学際的融合に おいて多くの研究者が光を用いている，そこで本学会 に打ける光関連トピックスを広く7つ取りあげる“七 色の光” 特集を企画した。 具体的には，「生物がいか に光を利用しているのか（生物がみる光）」について， 光をエネルギーとして利用する例，情報として利用す る例，そして自ら光を発する例とその応用，また「生 物を観察・操作するのにどのように研究者が光を利用 しているのか（生物をみる光）」について，顕微鏡や レーザーのようなラボレベルでも利用できる実験装置 から放射光のよらな大型実験施設，さらに光で生物を 人為的に操作する新技術，それぞれをトピックスとし て取りあげた。
言らまでもなく，生命は太陽の光により育まれてき た.太陽光を細胞のエネルギーに変換し地球上の生物 は利用している。動物は自ら光エネルギ一変換システ ムを持たないため，専ら他の生物の恩恵に与ってい る. 昨今のエネルギー問題の解決のため, このよらな 自然のシステムから学ぶところは多い。束た，多くの 生物は光環境の変化を知覚して自らの生命活動に活か している．特にヒトでは，外界の情報の $80 \%$ 以上を眼 からの視覚刺激で得ていると言われる。そのため，月 もない星空の夜から，夏の太陽が降り注ぐ真昼まで, 光強度がダイナミックに変化する状況に対応できるシ ステムを持っている. 光波長にしても $400 \sim 700 \mathrm{~nm}$ の範囲で波長を区別して認識できるおかげで，水墨画 の墨の濃淡だけでなく，鮮やかな色彩の絵画を楽しむ ことができる，さらには，生物の中には光を受容する だけでなく蛍光や発光として自ら光を発するものもい る. 子供の頃，川で見たホタルや水族館で見たクラゲ などの発する幻想的な光に魅了された記憶は忘れられ ない。それらのシステムの解明が進むことにより開発 された蛍光・発光タンパク質は，生命現象の理解に抒 いて絶大な威力を発揮している.

光はその直進性・高速性などの性質から，「光技術」 として生命の観察・理解にも広く利用されてきた. 17 世紀にロバート・フックは顕微鏡でコルクを観察し “cell”と名付けた（観察記録を掲載した“Micrographia” の発刊から今年でちょらど 350 年になる）が，21 世紀 の現在では超解像顕微鏡を用いて生きた細胞で 1 分子 の挙動や細胞内小器官の微細構造を観察できる．先に 述べた蛍光分子との組み合わせで可能性はますますふ くらんでいる。また，生体高分子が機能を発現するの に必要な構造変化ダイナミクスを解明するために,

Foreword to a Special Issue of "Light to Maintain Life and Light to Observe Life: Seven-colored Light Illuminating Biophysics" Takahiro YAMASHITA and Yasushi IMAMOTO

Department of Biophysics, Graduate School of Science, Kyoto University 
レーザーの高速化や小型化は多大な貢献をしてきた. 特に, 超短パルスレーザーの開発により，ピコ秒や フェムト秒で起こるタンパク質の初期化学反応を観察 することが可能になり, 生物学と量子力学を結び付け た.さらには, SPring-8 や Photon Factory に代表され る大型放射光施設は，今では構造生物学に欠かすこと のできない施設であるばかりでなく，さまざまな研究 の拠点になっている．施設の運営に携わる方々の不断 のご尽力により，本学会会員の多くも垣根を低くして 利用することが可能になっている.

最近，光を用いて低侵襲的に生命現象を人為的に操 作する技術が大きな進展を見せている. 光遺伝学（才 プトジェネティクス）と呼ばれる技術である，光駆動 性陽イオンチャネル（チャネルロドプシン）を用いて 神経細胞の興奮を光で誘起できることがわかり，これ を契機にして種々の光受容タンパク質をベースにした オプトジェネティクスッールを用いる研究が汎用的に なりつつある。このような技術の爆発的な進展は，そ れまでに培われた関連タンパク質の構造・機能の研究 があってこそのことである.

ここでとりあげたもの以外にも本学会では多くの興 味深い光関連トピックスがあるが，誌面の都合等もあ り今回は7つに絞らせて頂いた。 ご理解を頂けると幸 いである，本特集を企画するにあたり，原田慶恵編集 委員長を始め編集委員の先生方には有益なご助言を頂 いた。また，執筆にあたっては，各トピックスにおい て第一線で活躍される先生方が，拈忙しい中扮引き受
け下さった。この場を借りて深く感謝を申し上げた い，その扐かげで，ふと空を見上げて七色の虹を見つ けるとられしくなる，そらいったワクワク感を味わっ て頂ける話題が各記事に散りばめられている。そし て，本特集を含む光関連トピックスを反映して，近い 将来，本学会で新たな“七色の光”を生みだすことが できるように貢献したいと思ら。ちょうど，きれいな 青空に虹が描かれると, 傍らにもら一本虹が浮かんで 二本の “七色の虹”が鮮やかに共演するように。

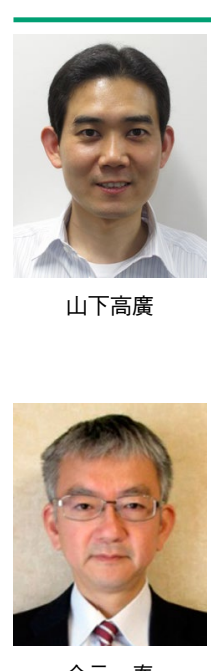

山下高廣（やました たかひろ） 京都大学大学院理学研究科助教 京都大学博士 (理学), 日本学術振興会特別研究 員（PD）を経て 2004 年より現職. 研究内容:動物のロドプシンなど $\mathrm{G}$ タンパク質共 役型受容体の機能発現メカニズムの解析 連絡先: 7 606-8502 京都市左京区北白川追分町 E-mail: yamasita@rh.biophys.kyoto-u.ac.jp URL: http://photo1.biophys.kyoto-u.ac.jp/shichida/ home_jp.html

今元 泰 (いまもと やすし) 京都大学大学院理学研究科准教授 京都大学博士 (理学), 大阪大学理学部助手, 奈 良先端科学技術大学院大学助教授を経て 2006 年 より現職.

研究内容:光センシングの生物物理学

連絡先:同上

E-mail: imamoto@rh.biophys.kyoto-u.ac.jp URL: 同上 